\title{
The impacts of COVID-19 pandemic to informal economic sector in Indonesia: Theoretical and empirical comparison
}

\author{
Agus Joko Pitoyo ${ }^{12^{*}}$, Bagas Aditya ${ }^{2}$, and Ikhwan Amri² \\ ${ }^{1}$ Center for Population and Policy Studies, Universitas Gadjah Mada, Yogyakarta, 55281, Indonesia \\ ${ }^{2}$ Environmental Geography Department, Faculty of Geography, Universitas Gadjah Mada, Yogyakarta, 55281, Indonesia
}

\begin{abstract}
The COVID-19 pandemic has caused a global multidimensional crisis, one of its impacts being the crisis on the informal economy. This paper presents a review of the effects of this pandemic on the informal economy, coupled with empirical evidence based on surveys conducted in Indonesia. Data used in this study was collected by an online survey during the pandemic. Theoretically, there are two points of view about the informal economy roles during a crisis: optimistic views that see informal economy survive in a crisis and pessimistic views that see the ongoing informal economy continue to suffer losses and also informal workers as vulnerable groups during a crisis. The research also discussed the impacts of the crisis triggered by the COVID-19 pandemic on informal employments and incomes, readiness in dealing with the pandemic, and the livelihood conditions of informal workers. The crisis as a result of this pandemic provides a new experience for the informal sector in dealing with the crisis. The informal sector is not always a hero during the crisis but rather an alternative sector that offers business flexibility.
\end{abstract}

\section{Introduction}

At the end of December 2019, an infectious disease called COVID-19 (formerly 2019-nCOV) spread in the city of Wuhan, China. The disease that attacks the human respiratory tract is known to be caused by a pathogen in the form of SARS-Cov-2 (Severe Acute Respiratory Syndrome Coronavirus 2) [1-2]. In contrast to previous zoonotic viruses, Severe Acute Respiratory Syndrome Coronavirus (SARS-Cov) and Middle East Respiratory Syndrome Coronavirus (MERS-Cov), SARS-Cov-2 has a faster spread rate with lower mortality [3]. The total positive confirmation of COVID19 in China reached more than one thousand cases in only about one month since the first case was announced [4]. This virus then began to spread to other countries so that the World Health Organization (WHO) announced the virus as a pandemic on March 11,2020, along with the increasing spread of the virus uncontrolled throughout the world.

Indonesia is one of the countries affected by the epidemic of COVID-19. The total confirmed reached more than ten thousand cases since the beginning of May 2020 [4]. The Indonesian government has made several decisions to minimize the spread of the virus, such as calls for implementing physical distancing, restrictions on activities involving large crowds, to large-scale social restriction policies (called PSSB). The existence of this policy certainly has impact on the economic conditions of society. Limited community activity will cause a weakening of economic productivity, especially in the type of economic activity that depends on the level of daily consumption of the community. The COVID-19 is also estimated to have impacts on retail activities, transportation, manufacturing, and labor supply [5].

The condition of the common economic crises was different from the crisis that occurred during an epidemic disaster. This is because the pandemic did not directly attack the economic structure, but rather started from the general living system of the community. Thus, the economic crisis that occurred during the COVID-19 outbreak was a secondary impact. It should be noted that the crisis caused by the outbreak has global impacts since it was declared a pandemic. The impacts of epidemics on the economy had previously been widely studied. Infectious diseases caused agricultural productivity to decrease in rural areas of developing countries [6]. Gatiso stated that the Ebola virus outbreak has played a role in reducing household incomes, posing threats to food security, and degradation of social capital in Liberia [7]. Meanwhile, research on the impacts of the Human Immunodeficiency Virus (HIV) outbreak in Africa showed that this outbreak has reduced young people's access to livelihood assets [8].

The informal economy is one of the main concerns due to the impact of the multidimensional crisis caused by the COVID-19 pandemic. It has been agreed that informal workers are a vulnerable group because they are generally low-incomes and do not have social security. This condition is certainly a big challenge for low and middle-income countries, where the level of informality is relatively high. The largest proportion of informal workers is in Africa at $85.8 \%$, followed by Arab and Asia-Pacific countries with proportions of

\footnotetext{
* Corresponding author: aguspit@ugm.ac.id
} 
$68.6 \%$ and $68.2 \%$ respectively [9]. Indonesia is also included as a country that has a higher share of informal employment than formal employment. The Central Statistics Agency noted that the country had a proportion of $57.3 \%$ of informal workers in 2019. The COVID-19 pandemic was estimated to be a shock for informal workers because it could have an impact on their jobs and incomes.

Several studies have described the adverse effects of the epidemic on the economy. However, the impacts of the COVID-19 outbreak on the informal economy is still unclear. Various theories and previous studies have also explained the impacts of the crisis on the informal economy but are not specific to the crisis conditions due to the epidemic disaster so it becomes a kind of puzzle that needs to be completed. Understanding the impacts of outbreaks on the informal sector is useful in developing the concept of informal sector resilience to new types of crises and is also useful in the formulation of government policies in maintaining the sustainability of the informal sector during and after outbreaks. This paper presents an overview of the impacts of the crisis on the informal economy. This study also aims to analyze the impacts of COVID-19 on the informal economy with case studies in Indonesia from the results of the initial survey. The findings are further discussed with the results of literature studies to obtain an overview related to the development of theories relevant to the resilience of the informal economy.

\section{Research method}

This study uses data collected by the Center for Population and Policy Studies (PSKK) of Gadjah Mada University, news, official press releases from the Task Force for the Acceleration of Handling the COVID-19, and related journals. Data collected by PSKK are the result of structured interviews with 235 informal workers in Indonesia. Due to the emergency conditions, the survey was conducted by distributing online questionnaires on April 8 to April 17, 2020. Furthermore, data analysis was carried out using descriptive statistics and comparative descriptive methods to explore and compare empirical findings with existing concepts or theories from previous studies.

\section{Result and discussion}

\subsection{Informal economy and crisis}

The informal economy is an economic activity that is not taxed and is not under government observation. In the informal economy, there are usually two terms namely the informal sector and informal workers. The informal sector is defined as a business that is not a legal entity owned by households or individuals [10], while informal worker refers to a worker who is not registered nor protected by the legal framework, does not have work contracts, secure work incomes, benefits workers, and social protection [11]. In several studies, both sector and worker is classified in one form of activity, namely informal sector activity.

The informal sector tends to be identified with smallscale activity, less productive, and does not have promising prospects [12]. This sector in general is more commonly found in rural areas. However, this sector can also be found in urban areas, where the number of formal employment opportunities often cannot match the number of migrant job seekers as a consequence of urban bias [13]. On the other hand, the ability of the informal sector to survive during a crisis has long been a concern among researchers. In general, there are two views regarding the informal sector and crisis. One side is optimistic that the informal sector can survive during a crisis, while there are those who argue that the informal sector is unable to survive.

The optimism viewpoints position the informal sector as a buffer sector. In this view, the informal sector becomes a path for people who lose jobs or incomes during the macroeconomic crisis. The flexibility of the informal sector in receiving capital and human resources provides a great opportunity for the community to look for incomes during a crisis. The informal sector is seen as a safety net for workers. Castels and Portes stated that one of the informal sectors emerged as a reaction to the economic crisis that occurred [13]. Macroeconomic crises are usually characterized by their impact on decreasing investment which then causes companies to reduce production costs so they don't suffer losses. One of the costs of production that can be reduced is the cost of wage labor. In times of crisis, there will usually be a decrease in salaries or layoffs. The informal sector in this condition acts as a safety net for laid-off workers [14].

The flexibility of the informal sector is characterized by the ease of being reached by people without having certain educational or skill qualifications. That is why this sector can be alternative employment during a crisis. In Côte d'Ivoire, community participation in the informal sector through micro-businesses is a way out for survival in times of crisis [15]. Meanwhile, the informal sector at the time of the 1998 crisis in Indonesia also showed its ability to survive the current monetary economic crisis in Indonesia [16]. The informal sector also showed a positive response to the crisis in Turkey, both internal and external crises with positive impacts that lasted relatively long for 10 years after the crisis [17]. The informal sector is indeed a sector that is relatively less productive. However, although the incomes earned in the informal sector is relatively lower, the informal sector is the best way for people to survive during a crisis. In times of crisis, people will tend to think pragmatically, so that the level of productivity is not a major consideration because the most important thing is to survive [13]. The view of the informal sector serves as a buffer during the crisis also put forward by Colombo et al. based on empirical analysis on a sample of many countries [14]. The findings showed that there is a tendency for an increase in the supply of informal labor during a crisis. This is also associated with a decrease in demand for formal labor and an increase in unemployment. Many of the formal workers turn to informal workers as an alternative strategy to survive 
during the crisis so that the phenomenon of informalization emerges.

The informal sector may be able to act as a safety net during a crisis, but this sector is actually the same as the formal sector which will be adversely affected by the crisis. The pessimistic views tend to see it from an employment perspective. Workers in this sector are considered as vulnerable groups. In addition, this view also sees the impacts of the crisis on the existing informal sector, not on the potential of the informal sector that will emerge during a crisis.

The people working in the informal sector are basically one example of vulnerable workers [19]. Vulnerable workers are those who do not have certainty in contracts and working hours, and uncertain guarantees. The International Labor Organization (ILO) groups vulnerable workers as self-employed and unpaid family workers. Vulnerable workers are relatively more affected by the economic crisis because these types of workers do not have stable incomes. In addition to not having employment guarantees such as formal workers, informal workers also do not have financial guarantees in the event of loss during a crisis [20]. Informal economic activities also do not have a clear market competition mechanism, so the dynamics that occur are actually more unpredictable compared to other formal sectors. This certainly has an impact on the vulnerability of the informal sector during crises where the existing informal sector is likely to suffer losses due to increased competition entering the informal sector during a crisis. Mahrota stated that in times of crisis, workers in the informal sector need to get social insurances and social assistance from the government [20].

Horn criticized the view of the informal economy as a safety net during a crisis [21]. Informal workers indeed do not have economic and social protection even though the crisis does not occur. Although the number of informal workers can increase during a crisis, this does not mean that there is an informal sector development. The crisis conditions place informal workers into worse vulnerability and even fall into poverty. Based on an empirical study in Serbia, Jaskova also stated that informal employment cannot be a safety net for those who are formally unemployed during a crisis [22]. It was proved by the decline in the percentage of the number of informal workers that is higher than the formal sector after the 2008 global economic crisis (until 2013). It showed that informal employment was considered more vulnerable than formal employment.

Differences in views on the ability of the informal sector to survive during the crisis are basically influenced by the views on these economic activities. The optimistic views see the informal sector as a container for economic activity. The informal sector which is realized in the form of business with small capital is considered to be a safety net during a crisis because informal businesses still have production efficiency. Meanwhile, the pessimistic views see the informal sector in terms of the labor force involved in it. The pessimistic views emphasize the informal sector as an economic activity that has existed since before the crisis, in this view the informal sector especially its work will get negative impacts during a crisis such as incomes uncertainty and the absence of social security. Based on a review of previous studies, several points of view differences can be seen in Table 1 .

\subsection{Preliminary findings of COVID-19 impacts on informal workers in Indonesia}

This section explains the initial findings of the impacts of COVID-19 on the conditions of informal workers in Indonesia. Respondents in this study consisted of 239 informal workers with a predominance of $25 \mathrm{yr}$ to $55 \mathrm{yr}$ old $(88.5 \%)$. About 134 of them are non-agricultural informal workers, while the rest work in the agriculture field. In general, informal workers have relatively low incomes. This is in accordance with the condition of respondents' characteristics in the study. The dominant average incomes are less than IDR2500000 per month (63.4\%). Most respondents also have incomes with an uncertain pattern since normal conditions (69.4\%). Furthermore, this section explains the impacts of the COVID-19 outbreak on their incomes and job

Table 1. Summary of views on the ability of the informal economy to survive during a crisis.

\begin{tabular}{|c|c|}
\hline Optimistic Views & Pessimistic Views \\
\hline $\begin{array}{l}\text { Point of view: focusing on informal economy as } \\
\text { economic activity }\end{array}$ & $\begin{array}{l}\text { Point of view: focusing on labor force on informal } \\
\text { economy (informal labor) }\end{array}$ \\
\hline $\begin{array}{l}\text { 1. Activities in the informal sector have the } \\
\text { flexibility to absorb labor without requiring } \\
\text { certain qualities }\end{array}$ & $\begin{array}{l}\text { 1. Informal workers belong to the class of } \\
\text { vulnerable groups }\end{array}$ \\
\hline $\begin{array}{l}\text { 2. Business in the informal sector does not } \\
\text { require large financial capital, so it can be } \\
\text { done despite the crisis }\end{array}$ & $\begin{array}{l}\text { 2. Informal workers do not have the guarantee of } \\
\text { employment, social security and other } \\
\text { guarantees needed in a crisis }\end{array}$ \\
\hline $\begin{array}{l}\text { 3. Activities in the informal sector can absorb } \\
\text { workers affected by layoffs due to the crisis }\end{array}$ & $\begin{array}{l}\text { 3. The impact of the crisis on the informal sector } \\
\text { that existed before the crisis is the same as in } \\
\text { the formal sector or worse }\end{array}$ \\
\hline $\begin{array}{l}\text { 4. Informal sector activities are easier to carry } \\
\text { out during a crisis so that they are able to } \\
\text { provide security in a crisis }\end{array}$ & $\begin{array}{l}\text { 4. The informal sector before the crisis had } \\
\text { income uncertainty. It could get worse during } \\
\text { a crisis }\end{array}$ \\
\hline
\end{tabular}


conditions, preparedness in dealing with the pandemic itself, and livelihood conditions, both for agricultural and non-agricultural informal workers.

\subsubsection{Impacts on incomes and jobs}

Figure 1 shows the impacts of COVID-19 on the incomes of informal workers. Most workers experienced a decline in incomes, both in agriculture (65 respondents) and non-agriculture (74 respondents). Informal workers also experienced a lot of lost incomes altogether $(33.2 \%)$. This is caused by the policy of limiting the intensity of human encounters to reduce the transmission rate of the virus spreading, thereby triggering disruptions to demand and supply. Only a few informal workers whose incomes are not decreasing or lost during pandemic $(7.7 \%)$.

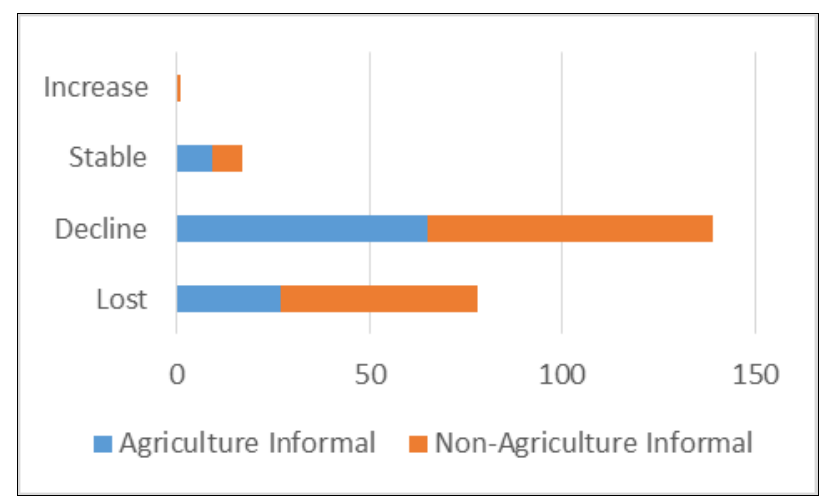

Fig. 1. Impacts of COVID-19 on the incomes.

As many as $64.4 \%$ of respondents working in informal agriculture experienced a decline in incomes and $26.7 \%$ of respondents even lost their incomes because the market system and supply chain were disrupted. During a pandemic, people's purchasing power has diminished. Some agricultural products experienced price shocks. Many informal agricultural workers suffer losses because products sold after harvest cannot cover production and maintenance costs. The same situation also occurs in agricultural informal workers, where $55.2 \%$ of respondents answered decline, while $38.1 \%$ of respondents answered lost. This form of loss basically varies based on product types (goods or services).

Changes in incomes during the COVID-19 pandemic are certainly related to job conditions (Figure 2). Most respondents claimed that they lost their jobs with $72.2 \%$ of them were non-agricultural informal workers. However, $32.8 \%$ of respondents answered that they continued to work with the same type of work even though the pandemic had caused socio-economic disruption. This option ranks second highest after the previous answer and the proportion between agricultural and non-agricultural informal workers did not differ significantly. Meanwhile, the rest answered switching jobs as an alternative strategy for earning incomes. Compared to the first answer, this choice was answered more by agricultural informal workers with a proportion of $63.2 \%$.

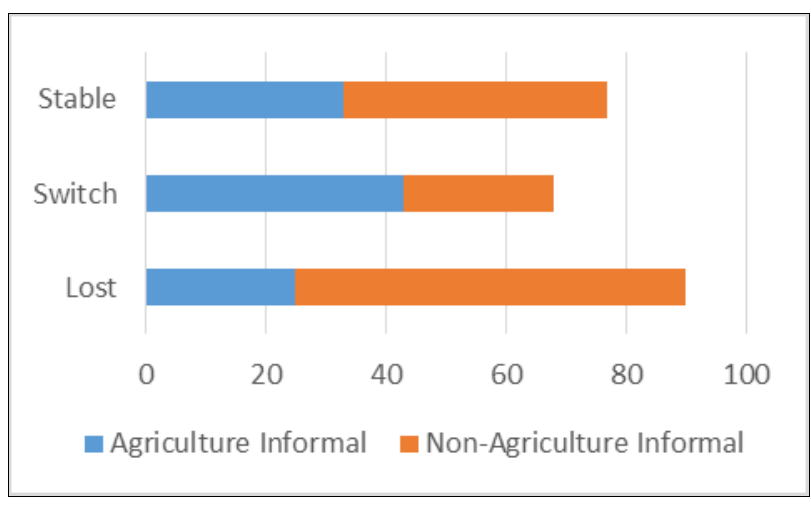

Fig. 2. Impacts of COVID-19 on the main job.

\subsubsection{Readiness to face COVID-19}

Informal workers do not have health insurance as obtained by formal workers. Interestingly, the majority of informal worker respondents $(54, .9 \%)$ said they were ready in terms of health to face a pandemic over the next 2 months (Figure 3). There is no significant difference between agricultural and non-agricultural informal workers. Meanwhile, the proportion of informal workers who answered doubt and not ready was $30.6 \%$ and $14.5 \%$ respectively. This paradox can occur because the informal workers actually consider job loss or incomes as worse impacts than the virus spreading itself.

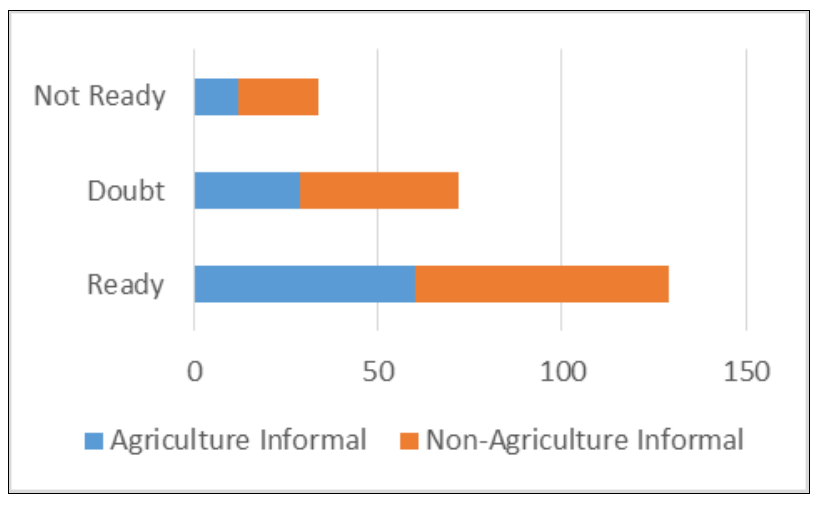

Fig. 3. Health readiness for the next 2 months.

This also relates to their readiness if the government does a total lockdown during the pandemic. Lockdown means there should be no activities that involve many people at all without urgency, including economic activities. Based on Figure 4, most informal workers $(37.0 \%)$ answered that they were not ready if lockdown was implemented. About $32.3 \%$ of respondents were doubtful, while the rest stated they were ready. Nevertheless, there are significant differences in answers when viewed from the field of job. Most respondents of agricultural informal workers $(38.6 \%)$ claimed to be ready, while the majority of non-agricultural informal workers $(41.8 \%)$ answered that they were not ready if total lockdown applies. The incomes and jobs of 
informal workers have been severely affected even though the government is limited to implementing physical distancing to reduce the rate of virus transmission. The paralysis of economic activity can put them into deeper poverty. In other words, economic disruption is considered more dangerous than the epidemic itself for vulnerable groups.

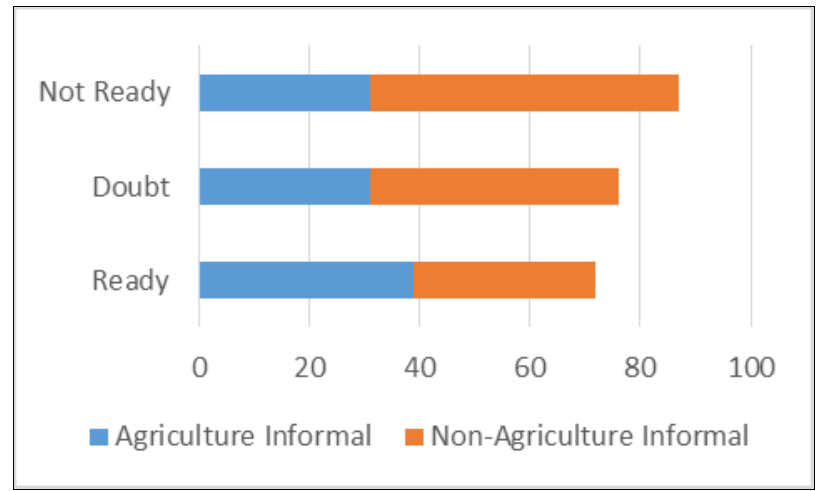

Fig. 4. The readiness of informal workers if total lockdown policy is applied.

\subsubsection{Livelihood conditions of informal workers}

This study also asked how household logistics are available during the COVID-19 emergency, referring to the existing conditions (Figure 5). Most respondents $(34.5 \%)$ answered only enough for less than 1 week. The answer of nothing occupies the second-highest position $(32.8 \%)$. The rest answered more than 1 week, but the tendency is getting lower along with the increase in adequacy time. This evidence shows the vulnerability of informal workers during the pandemic. They do not get stable incomes since normal conditions, especially if it is worsened by the conditions of the crisis so that it can affect their livelihoods.

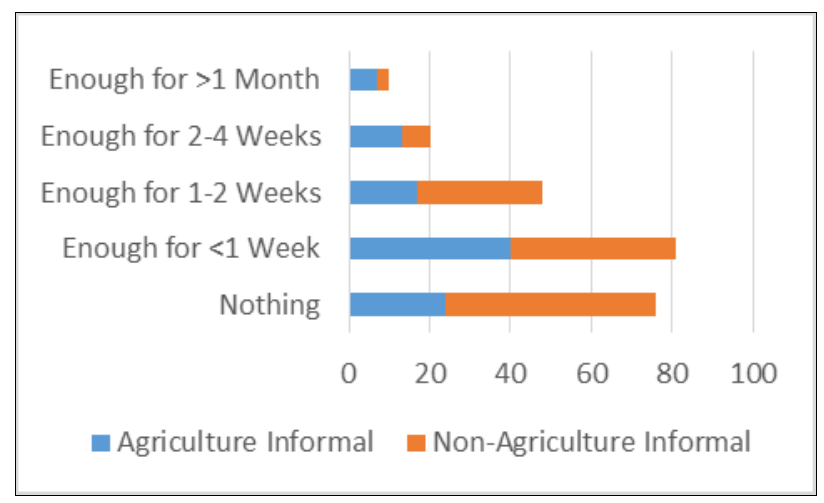

Fig. 5. Availability of household logistics.

The results also show that agricultural informal workers tend to have sufficient availability of household logistics for longer periods of time compared to nonagricultural informal workers. The answer is thought to correlate with readiness if total lockdown is applied. People who have more logistical supplies tend to be better equipped to deal with that policy.
Finally, respondents were asked about their ability to survive for the next 2 months (Figure 6). Many of them feel unsure of their ability to survive amid the crisis conditions. A total of 123 respondents (50.6\%) answered doubtfully. This condition is also compounded by uncertainty during this time frame because there are no signs of improving the situation. The other two answer options have almost the same proportions. However, the answers of not able to survive far dominated by non-agricultural informal workers.

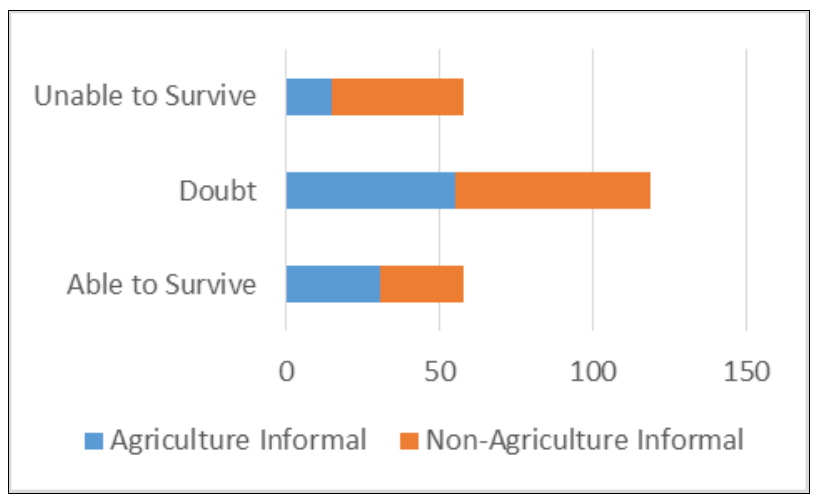

Fig. 6. Ability to survive for the next 2 months.

\subsection{New insights from COVID-19 related to the informal economy}

Indonesia's economy has been rocked by several economic crises. In less than 30 years before the COVID-19 pandemic occurred, Indonesia had at least been affected by two economic crises. The first crisis, referred to as the Asian Financial Crisis (AFC), occurred in 1997/1998, while the last crisis, referred to as the Global Financial Crisis (GFC), occurred in 2008/2009. Both are equally influenced by the dynamics of the global economy and cause a decline in economic growth in Indonesia (Figure 7). However, the most significant impacts occurred in 1997/1998, where Indonesia's economic growth rate had reached $-13 \%$ [23]. Meanwhile, Indonesia was still able to maintain its rate of economic growth above zero during the 2008/2009 crisis despite the decline. Learning from the experiences of the two previous crises, the sector most affected in general is the formal sector, which is characterized by a wave of massive layoffs and then also followed by a wave of job informalization $[12,16,24]$. The informal economy in the $1997 / 1998$ and 2008/2009 crisis conditions proved to be relatively more resilient than the formal sector.

The economic crisis is estimated to occur again in Indonesia as a logical consequence of the obstruction of production, distribution, and consumption due to COVID-19. The Indonesian Ministry of Finance predicts the worst scenario of the impacts of this pandemic is the decline in Indonesia's economic growth from 5.3\% to $0.4 \%$, the number of poor people rising 4.86 million people, and the number of unemployed increased by 5.23 million [25]. The pandemic in this crisis did not directly attack the country's financial system or the national and 


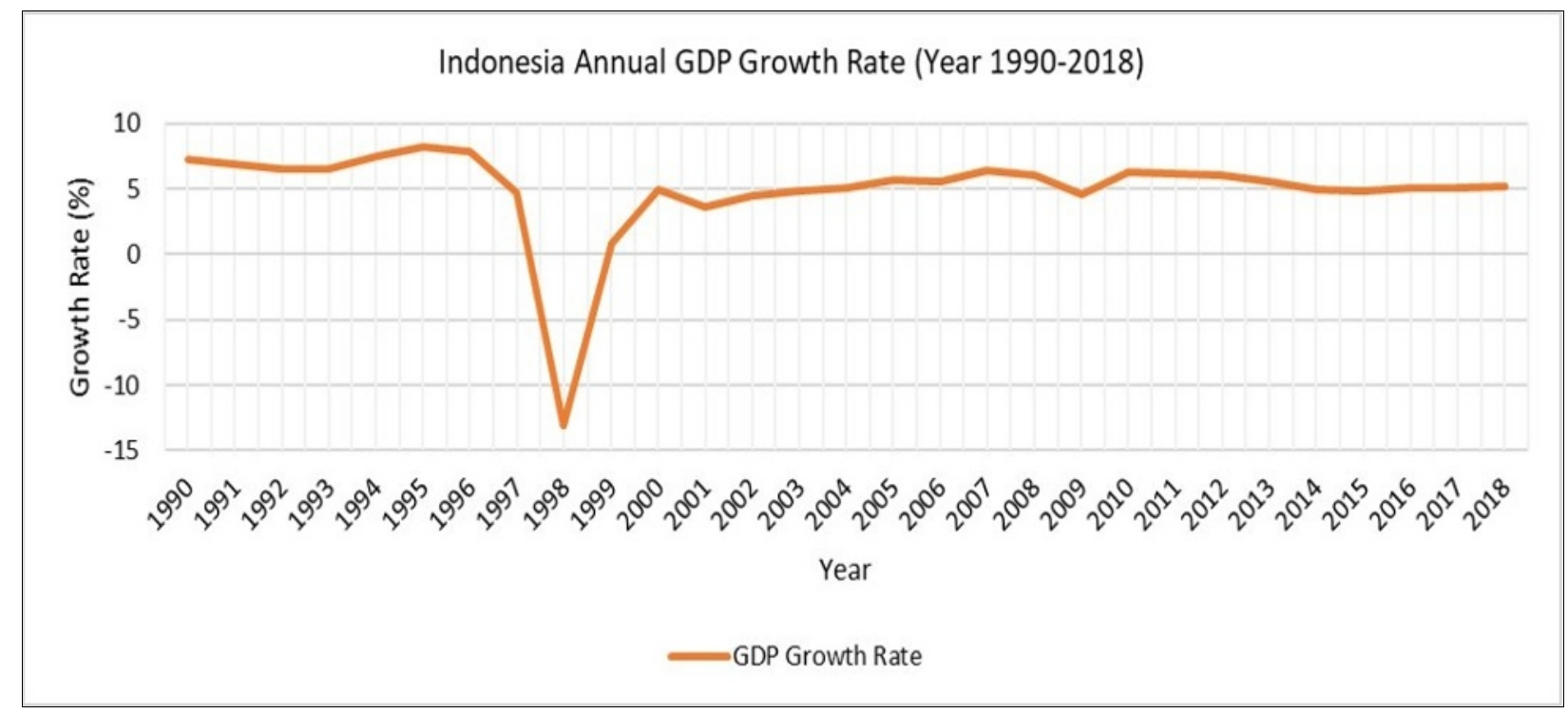

Fig. 7. Economic growth of Indonesia in 1990-2018 [23].

global stock investment system, but instead attacked the grassroots economic system which then spread to macroeconomic conditions. The World Bank states that the baseline forecast envisions a $5.2 \%$ contraction in global GDP due to this pandemic [26].

The big question is whether the informal sector can survive a pandemic compared to the general economic crisis? There are two answers, if you look at the existing informal sector activities, of course the answer to the informal sector is not able to maintain productivity during a pandemic. Informal economic activity in Indonesia in the previous crisis was able to survive because it was relatively more resistant to macroeconomic disruption. But during this pandemic, the opposite happened. The reduction of community activities on the grounds of preventing virus spreading makes it difficult for the informal sector to survive during a pandemic, especially as the informal sector in Indonesia is dominated by economic activities that rely on daily consumption. Samir states that one of the causes of the vulnerability of the informal sector during the COVID-19 pandemic in Indonesia is that the sector is not well-recorded so that the government cannot provide guarantees of protection against losses faced by the informal sector [27]. Furthermore, the ILO also stated that the informal sector tends to be vulnerable during an outbreak. It has low productivity, low levels of investment and savings, capital accumulation that cannot be used, and is often excluded from government assistance because it is not well recorded [28]. This pandemic will be a time of concern for developing countries with a third of GDP and more than $70 \%$ of the workforce in the informal sector [26].

Beyond the fact the deterioration of the informal sector in Indonesia during the outbreak, basically there is still the possibility of this sector to be said to be more resilient than the formal sector. Informal economic activities are activities that are dynamic and can be carried out by anyone without certain qualifications, so it is logical if this sector is possible to be more resilient and recover quickly after the pandemic, especially after regional quarantine or PSBB is ended. Economic activities in the informal sector are relatively more resilient because they have the flexibility of the minimum capital required and the qualifications of their workforce. The allocation of social assistance from the government can actually still be utilized by the community to carry out informal economic activities during and after the pandemic. In addition, the informal sector in Indonesia when COVID-19 was considered to be a hero in absorbing excess labor after this pandemic. Foreign workers returning, laid-off workers, or new workforce has the opportunity to fill informal economic activities, not because the informal sector offers high wages but because the informal sector has relatively no competition compared to the formal sector. In the informal sector, everyone can do activities and get incomes. However, Samir argues that the informal sector should not be used as a secondary sector in sustaining the national economy, the informal sector is actually only an alternative sector during an outbreak [27].

\section{Conclusion and recommendation}

The impacts of the COVID19 pandemic crisis on the informal sector in Indonesia shows a different pattern from the economic crisis experienced by Indonesia especially in $1997 / 1998$ and $2008 / 2009$. The crisis due to the corona outbreak which led to a policy of limiting community activities greatly affected the decline in economic productivity to a lower level, including the informal sector. The empirical fact of the impacts of COVID19 on the informal sector in Indonesia shows that the resilience of the economic sector to the crisis cannot be equalized, different types and causes of the crisis affect the different levels of impacts.

This study provides a preliminary picture that informal workers, both in agriculture and nonagriculture, were affected by the crisis triggered by the 
COVID-19 pandemic. Most respondents felt the crisis had a negative impact on their work and incomes. Surprisingly, this study found informal workers feel ready to deal directly with the outbreak. However, most of them feel unprepared if the lockdown applies, which means economic activity will be completely paralyzed. This evidence shows that health disasters are no more feared than secondary effects caused by a pandemic. Judging from their living conditions, these results indicate that informal workers are vulnerable groups who need to get more attention. Many informal workers are doubtful or unable to bounce back from the crisis with increasingly unstable incomes conditions.

Initial studies analysis found that the informal sector in general did not survive the crisis due to the pandemic. The informal sector especially informal workers are considered more vulnerable because they do not have clear health and employment guarantees. The solution offered by the ILO in saving the informal sector is to strengthen the health system to ensure financial access for all; building universal social protection, supporting the recovery of productive economic units, increasing productivity and facilitating the transition to the formal sector to increase formal employment opportunities. Although not immune to the effects of COVID19, businesses in the informal sector are estimated to be more resilient to restore productivity than businesses in the formal sector because they have greater flexibility in carrying out economic activities. However, this is different from informal workers who feel they will not be able to recover their incomes after the pandemic and have the potential to transfer jobs.

This research still has some limitations. First, the data was not obtained from a probability-based survey design so the results cannot yet be generalized to the informal economy as a whole. However, these results provide at least a preliminary overview of how the COVID-19 pandemic affected informal workers in Indonesia. Second, informal workers' strategies for surviving this crisis still need to be explored further by using more detailed survey methods. This paper also recommends further studies to identify the symptoms of informalization during the crisis due to the COVID-19 pandemic to prove the role of the informal economy as a safety net.

This research is supported by the Center for Population and Policy Studies (PSKK) and Faculty of Geography, Gadjah Mada University.

\section{References}

1. C. Salata, A. Calistri, C. Parolin, G. Palu, Pathog. Dis. 17, ftaa006 (2020)

2. J.S. Mackenzie, D.W. Smith, Microbiol. Aust. MA2013 (2020)

3. T. Singhal, Indian J. Pediatr. 87, 10223 (2020)

4. M. Roser, H. Ritchie, E. Ortiz-Ospina, Coronavirus disease (COVID-19) - statistics and research, URL: https://ourworldindata.org/coronavirus. (2020)
5. W. McKibbin, R. Fernando, The global macroeconomic impacts of COVID-19: seven scenarios, CAMA working paper 19/2020 (The Australian National University, Canberra, 2020)

6. F.A. Mphande, Infectious diseases and rural livelihoods in developing countries (Springer Singapore, Singapore, 2016)

7. T.T. Gatiso, I. Ordaz-Nemeth, T. Grimes, M. Lormie, C. Tweh, H.S. Kuhl, J. Junker, PLOS Neglect. Trop. D 12, e0006580 (2018)

8. N. Ansell, F. Hajdu, L. Blerk, E. Robson, J. Rural Stud. 46, 23-34 (2016)

9. ILO, Women and men in the informal economy: $A$ statistical picture (ILO, Geneva, 2018)

10. ILO, Resolution concerning statistics of employment in the informal sector, adopted by the fifteenth international conference of labour statisticians (ILO, Geneva, 1993)

11. ILO, Informal economy workers, URL: https:/www.ilo.org/global/topics/wages/minimumwages/beneficiaries/WCMS_436492/lang-en/index.htm. (2020)

12. A.J. Pitoyo, Populasi 18, 129-146 (2007)

13. A.J. Pitoyo, Populasi 10, 73-97 (1999)

14. C.M. Firdausy, The social impact of economic crisis on employment in Indonesia, URL: http://www.ismea.org/asialist/Firdausy.html. (2000)

15. J.L. Lognon, D. Rusticot, C. Kablan, B. Obrist, Economic crisis, resilience, and the informal sector: An analysis of barriers to the creation of decent jobs, International Conference on Research for Development (ICRD 2012) Research for Global Transformation (2012)

16. T. Feridhanusetyawan, A.B. Gaduh, The Indonesian Quarterly 28, 295-315 (2000)

17. N. Kahyalar, B. Ouattara, S. Fethi, Athens Journal of Business \& Economics 6, 145-172 (2020)

18. E. Colombo, L. Menna, P. Tirelli, World Dev. 119, 1-22 (2019)

19. G. Standing, The precariat: The new dangerous class (Bloomsbury Academy, London, 2011)

20. S. Mehrotra, Glob. Soc. Policy 9, 101-118 (2009)

21. Z.E. Horn, Gend. Dev. 18, 263-276 (2010)

22. A. Jaskova, J. Hum. Resour. Manag. Res. 20, 11-20 (2017)

23. World Bank Group, GDP growth (annual \%), URL: https://data.worldbank.org/indicator/NY.GDP.MKT P.KD.ZG?locations=ID. (2019)

24. T.T.H. Tambunan, Modern Economy 1, 156-167 (2010)

25. Kementerian Keuangan RI, Atasi krisis akibat COVID-19, pemerintah responsif rumuskan program pemulihan ekonomi nasional, URL: https://fiskal.kemenkeu.go.id/baca/2020/06/06/1542 35339108256-atasi-krisis-akibat-covid-19- 
pemerintah-responsif-rumuskan-program-

pemulihan-ekonomi-nasional. (2020)

26. World Bank Group, The global economic outlook during the COVID-19 pandemic: A changed world, URL:https://www.worldbank.org/en/news/feature/2 020/06/08/the-global-economic-outlook-during-thecovid-19-pandemic-a-changed-world. (2020)

27. N. Samir, Economic heroes in time of coronavirus, URL:https://www.thejakartapost.com/academia/202 0/03/27/economic-heroes-in-time-ofcoronavirus.html. (2020)

28. ILO, Krisis COVID-19 dan sektor informal: Respons langsung dan tantangan kebijakan (Geneva, ILO, 2020) 